\title{
Regenerating Gene Protein as a Novel Autoantigen in the Pathogenesis of Sjögren's Syndrome
}

\author{
Takashi Fujimoto ${ }^{1}$, Kiyomi Yoshimoto ${ }^{2}$, Takanori Fujimura ${ }^{1}$, Maiko Takeda ${ }^{3}$, \\ Akiyo Yamauchi ${ }^{4}$, Asako Itaya-Hironaka ${ }^{4}$ and Shin Takasawa ${ }^{4, *}$
}

1 The Center for Rheumatic Diseases, Nara Medical University Hospital, 840 Shijo-cho, Kashihara 634-8522, Japan; E-Mails: tfujimot@naramed-u.ac.jp (T.F.); bowmoremacallan@yahoo.co.jp (T.F.)

2 Department of General Medicine, Nara Medical University, 840 Shijo-cho, Kashihara 634-8522, Japan; E-Mail: yoshimoto@banana.biglobe.ne.jp

3 Department of Diagnostic Pathology, Nara Medical University, 840 Shijo-cho, Kashihara 634-8522, Japan; E-Mail: maikot@naramed-u.ac.jp

4 Department of Biochemistry, Nara Medical University, 840 Shijo-cho, Kashihara 634-8521, Japan; E-Mails: yamauchi@naramed-u.ac.jp (A.Y.); iasako@naramed-u.ac.jp (A.I.-H.)

* Author to whom correspondence should be addressed; E-Mail: shintksw@naramed-u.ac.jp; Tel.: +81-744-22-3051 (ext. 2227); Fax: +81-744-24-9525.

Academic Editor: Dimiter S. Dimitrov

Received: 27 August 2015 / Accepted: 30 November 2015 / Published: 7 December 2015

\begin{abstract}
Sjögren's syndrome, an autoimmune disease characterized by exocrine gland dysfunction leading to dry mouth and dry eye diseases, is typified by lymphoplasmacytic infiltrations and a progressive destruction of the salivary and lacrimal glands. Despite an ever-increasing focus on identifying the underlying etiology of Sjögren's syndrome, the factors that initiate this autoimmune disease and the mechanisms that cause the subsequent exocrine gland dysfunction remain a mystery. The original explanatory concept for the pathogenesis of Sjögren's syndrome proposed a specific, self-perpetuating, immune-mediated loss of acinar and ductal cells as the principal cause of salivary gland dysfunction. We highlight the possible involvement of regenerating gene (Reg) in the regeneration and destruction of salivary gland acinar and ductal cells in Sjögren's syndrome. The Reg gene was originally isolated as a gene specifically overexpressed in regenerating pancreatic islets and constitutes a growth factor family (Reg family). We describe how salivary gland dysfunction is initiated and maintained and how it can be regenerated or progressed, mediated by the Reg gene, Reg protein, and anti-REG autoantibodies in Sjögren's syndrome.
\end{abstract}


Keywords: regenerating gene; anti-REG autoantibody; ductal epithelial cells; interleukin-6;

Sjögren's syndrome; Janus kinase; signal transducer and activator of transcription

\section{Introduction}

Sjögren's syndrome (SS) is a chronic inflammatory disease that affects the exocrine glands, particularly the salivary and lacrimal glands, leading to xerostomia and xerophthalmia and characterized by the presence of a variety of autoantibodies directed against organ- and non-organ-specific autoantigens. SS is a common systemic autoimmune disorder, affecting approximately $0.1 \%-0.4 \%$ of the general population, with a female to male ratio of $9: 1$, a prevalence comparable to that of rheumatoid arthritis [1-6]. It is known that the production of autoantibodies is an antigen-driven immune response as certain autoantibodies are disease-specific, contain multiple epitopes, and the autoimmune response is perpetuated and augmented via intra- and inter-molecular spreading against the same or other autoantigens. It is unknown whether any of the autoantibodies has a direct pathogenic potential or if they merely participate in a secondary response to salivary glands that are already damaged by another process. Although the pathogenetic mechanisms of this autoimmune exocrinopathy are not yet fully known, SS arises either as the primary disease or occurs secondary to other autoimmune rheumatic diseases as a result of infiltration of the functional glandular epithelium by autoreactive lymphocytes [7]. The original explanatory concept for the pathogenesis of SS proposed a specific, self-perpetuating, immune-mediated loss of acinar and ductal cells as the principal cause of salivary gland dysfunction. Accordingly, apoptosis, fibrosis, and atrophy of the salivary glands would represent consequences of salivary gland hypofunction.

The regenerating gene, $R e g$, was originally isolated from a rat regenerating islet cDNA library [8-10]. The Reg and Reg-related genes were isolated and revealed to constitute a multigene family, the $R e g$ family, which consists of four subtypes (types I, II, III, and IV) based on the primary structures of the encoded proteins of the genes [9-11]. Reg family gene products act as growth factors and promote cell proliferation and regeneration, and therefore are considered to be important for various inflammatory diseases [9-12].

REG I $\alpha$ mRNA as well as its product (REG I $\alpha$ protein) were overexpressed in ductal epithelial cells in the minor salivary glands (MSG) of primary SS (pSS) patients [13]. Furthermore, autoantibodies against REG I $\alpha$ were found in pSS patients, and the anti-REG I $\alpha$ autoantibody-positive patients showed significantly lower saliva secretion than the autoantibody-negative patients [13]. The mRNA levels of IL-6 and IL-8 were significantly higher in pSS MSG than those in normal MSG [13], suggesting that these cytokines may be involved in the overexpression of REG I $\alpha$ mRNA in pSS MSG. We aim to describe important pathogenetic mechanisms involved in the initiation and perpetuation of SS mediated by the regenerating gene, Reg, Reg protein, and autoantibodies against Reg protein.

\section{Pathogenesis of Sjögren's Syndrome}

The pathogenetic mechanisms responsible for SS are not yet fully elucidated, but in the presence of a susceptible genetic background, both environmental and hormonal factors are thought to be capable 
of triggering this autoimmune exocrinopathy. Salivary, lacrimal, and other exocrine glands become infiltrated with CD4+ T cells, but substantial numbers of B lymphocytes and plasma cells are also present in inflamed tissues. Moreover, glandular alteration in cell migration can also lead to the formation of germinal center-like structures that contain follicular dendritic cells and proliferating $\mathrm{B}$ lymphocytes $[14,15]$. Over the past 15 years, the importance of the epithelial cell in the pathogenesis and evolution of SS has been highlighted, prompting the use of the term "autoimmune epithelitis" as an alternative name for the disease [16].

Immunologically activated or apoptotic glandular epithelial cells that expose autoantigens in genetically predisposed individuals might drive autoimmune-mediated tissue injury. Critical to the initiation and perpetuation of SS pathogenesis are the upregulation of adhesion molecules and the production of chemokines and cytokines, which together promote the migration of lymphocytes and dendritic cells into the glands, maintaining their homing cycle. Extension of the pathological process that affects the exocrine glands into periepithelial and extraepithelial tissue can cause a considerable percentage of patients to exhibit systemic manifestations involving the lungs, liver, or kidneys. These manifestations develop as a result of lymphocytic infiltration or an immune-complex-mediated process, or both, and present as skin vasculitis coupled with peripheral neuropathy or glomerulonephritis.

A progressive loss of exocrine gland function due to glandular damage is induced by a lymphoid cell infiltration into these target organs. The autoimmune characteristics of the disease and diagnosis in patients with SS are made by focal lymphocytic sialoadenitis in MSGs with a focus score $>1$, defined as a number of lymphocytic foci (which are adjacent to normal-appearing mucous acini and contain more than 50 lymphocytes per $4 \mathrm{~mm}^{2}$ of glandular tissue) that test positive for SS autoantibodies (SS-A/Ro and SS-B/La) in the serum [17]. Histopathology usually exhibits lymphocytic infiltration, with the majority of CD4+ T lymphocytes in the minor salivary gland lip biopsy from SS patients in accompanying B lymphocytes [18-20]. Infiltrated lymphocytes are composed mainly of autoreactive CD4+ $\mathrm{T}$ cells [21], CD8 $+\mathrm{T}$ cells, and dendritic cells, and macrophages are also present. $\mathrm{T}$ cells preferentially express the T-cell receptor (TCR) V $\beta 6$ and TCR V $\beta 8$ in these tissues in an animal model [22]. In human lymphocytes consisting of T and B cells in the salivary gland, lesions have been reported [23,24]. Various studies indicate that human MSG biopsy tissue and salivary glands from mouse models exhibit helper T(Th)1-type cytokine profiles at the sites of target organs. An immunoregulatory role of Foxp3+ T-regulatory cells (Tregs) in the MSG is indicated as the occurrence of Tregs is positively correlated with inflammation grade [25].

An increase in several proinflammatory cytokines (and/or their mRNAs), including interleukin (IL)-1 $\beta$, TNF- $\alpha$, IL-6, IL-7, IL-10, IFN- $\gamma$, and inducible nitric oxide synthase (iNOS), was demonstrated in the submandibular glands of non-obese diabetic (NOD) mice, which were originally reported as a model for type 1 diabetes mellitus, a model for pSS with lymphocytic infiltrates [22]. Moreover, cytokine mRNA detected in lacrimal tissue was similar to that seen in the submandibular glands, but it appeared both earlier and more intensely [22]. Distinct subsets of CD4+ memory effector $\mathrm{T}$ cells, such as Th17 cells, may play an important role in various autoimmune diseases, including SS [26-29]. Moreover, the IL-23/Th17 pathway has been implicated in SS pathogenesis in Ro52-null mice, which develop systemic autoimmune disease resembling human lupus [27].

Autoantibodies may also play a role in pathogenesis. Serologically, the presence of rheumatoid factor, hypergammaglobulinemia, and antibodies to nuclear proteins, such as SS-A/Ro and SS-B/La [30], 
as well as antibodies against $\alpha$-fodrin [31], carbonic anhydrase II [32], and acetylcholine muscarinic 3 receptor [33], have been observed in the sera of SS patients. The latter could play a pivotal role in the secretory function of pSS [34]. In addition, there is a possibility that cryptic antigens are recognized by T lymphocytes and antibodies in autoimmune pathogenesis, including SS [35].

\section{Regenerating Gene}

\subsection{General Aspects}

The regenerating gene, $\operatorname{Reg}$, was originally isolated as a growth factor from a cDNA library of rat regenerating pancreatic islets [8-10,36]. Reg gene expression has also been identified outside of the pancreas. Subsequently, many Reg-related proteins have been identified in humans and other animals. The $R e g$ family genes constitute a multi-gene family, consisting of four subtypes [9,10]. In humans,

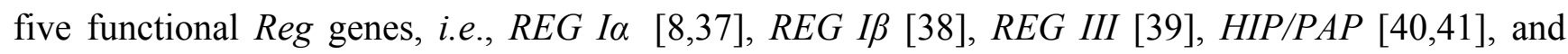
$R E G I V$ [42], have been isolated. Reg family proteins function as acute phase reactants, lectins, anti-apoptotic factors, and growth agents and include growth factors. These proteins are primarily involved in cell proliferation and differentiation, inflammation, diabetes, and carcinogenesis [9-12]. Type I (and type II) Reg proteins are expressed in regenerating islets [8,9,43,44]. Type III Reg proteins have been suggested to be involved in cellular proliferation in intestinal cells, hepatic cells, and neuronal cells. Importantly, mouse Reg III has been shown to be a Schwann cell mitogen that accompanies the regeneration of motor neurons [45], and Reg protein functions as a neurotrophic factor for motor neurons [46]. It has been reported that REG I protein is expressed in ductal epithelial cells in the MSG of patients with SS [47].

It has also been reported that $R E G$ family gene expression is regulated by several cytokines or chemokines, such as IL-6, IL-8, IL-11, IL-22, interferon (IFN) $\beta$, IFN $\gamma$, and cytokine-induced neutrophil chemoattractant (CINC)-2 3 [45,48-53]. IL-6, a pleiotropic proinflammatory cytokine, fulfills its functions through the activation of Janus kinase (JAK) and subsequent signal transducer and activator of transcription (STAT) [54,55]. STAT plays a key role in transmitting cytokine signals as a transcription factor, promoting cell proliferation and anti-apoptosis [56-59]. Involvement of STAT signaling in $R E G$ gene family expression in gastrointestinal epithelial cells and pancreatic $\beta$-cells has also been reported [51,52,60,61].

Autoantibodies against REG have been found in some diabetic patients [62,63]. However, the occurrence of autoantibodies against REG in SS patients was obscured. The presence of autoantibodies against REG might compromise the regeneration of damaged ductal epithelial cells. REG expression could be a key event in autoimmunity. This hypothesis is supported by the fact that the autoantibodies against REG have been shown to retard $\beta$-cell proliferation in vitro [62].

\subsection{REG, Cytokine, and Chemokine in Salivary Glands of Primary Sjögren's Syndrome}

We analyzed the mRNA levels of all the REG family genes (REG I $\alpha, R E G I \beta, R E G I I I, H I P / P A P$, and $R E G I V$ ) in the MSG of pSS patients using quantitative real-time reverse transcriptase-polymerase chain reaction (qRT-PCR) [13]. No REG I $\beta$ mRNA was detected either in the controls or in pSS MSG. The mRNA levels of REG III, HIP/PAP, and REG IV did not differ between the control and pSS MSG. 
In contrast, the mRNA level of REG I $\alpha$ in the MSG of pSS patients was significantly higher than that in the controls $(P=0.036)$.

We then analyzed REG I $\alpha$ protein expression in the MSG of pSS patients via immunohistochemistry. REG I $\alpha$ protein was stained strongly in the ductal epithelial cells in 28 of 53 samples (53\%), whereas acinar cells were immunostained in only two samples for REG I $\alpha$ [13]. In REG I $\alpha$-positive samples, the intensity of staining was not associated with the degree of inflammation, fibrosis, or acinar atrophy. These results support the idea that REG I $\alpha$ mRNA overexpression is associated with inflammation triggered by autoimmune disorders such as pSS.

It has been reported that $R e g$ gene expression is regulated by several factors, such as nicotinamide [48,64], glucocorticoids [48,65], nutrient factors [66], IL-6 [44,48,61], IL-8 [50], IL-11 [51], IL-22 [52], IFN- $\gamma$ [53], IFN- $\beta$ [44], and CINC-2 $\beta$ [49]. Among the major inflammatory mediators involved in the induction of inflammation of the salivary glands with pSS, IL-6 is an important proinflammatory cytokine in relation to lymphocyte infiltration [13,67]. In addition, the presence of IL-8 has been reported in salivary glands in pSS $[68,69]$. Additionally, IL-6 and IL-8 are reported to induce $R E G$ I $\alpha$ mRNA in vitro [48,50,61,66,70]. IL-11 [51], IL-22 [52], IFN- $\gamma$ [53], IFN- $\beta$ [44], and CINC-2 $\beta$ [49] are also reported to induce $R E G$ I $\alpha$ mRNA. IL-6 receptor (IL-6R) and gp130 are known as signal transducers of IL-6. We measured $I L-6, I L-8 I L-11, I L-22, I L-22 R, I F N-\gamma, I F N-\beta, C X C L 1$ (human homologue of $C I N C-2 \beta$ ), IL-6R, and gp130 mRNAs in the MSG via qRT-PCR [13]. The $I L-6$ mRNA level in the SS MSG was significantly higher than that in normal MSG. The $I L-8$ mRNA level in pSS MSG was also higher than that in normal MSG. The mRNA levels of $I L-11, I L-22, I L-22 R$, $I F N-\gamma, C X C L 1, I L-6 R$, and $g p 130$ in MSG were not significantly different between pSS patients and normal controls. The mRNA of $I F N-\beta$ was not detected in pSS MSG. We performed correlation analyses of the expression of cytokine mRNAs and REG I $\alpha$ mRNA and found that IL-6 mRNA expression was correlated significantly with $R E G I \alpha$ mRNA expression $(P=0.0018)$. These results suggest that the upregulation of cytokines, especially IL-6 and IL-8, induces overexpression of the $R E G$ I $\alpha$ gene in pSS MSG. We also examined the mRNA levels of $I L-6 R$ and $g p 130$ in pSS and normal MSG. The mRNA levels of $I L-6 R$ and gp130 were not significantly different between the two groups, suggesting that the increase of IL- 6 in the salivary glands of pSS patients can function as a switch for the IL-6/gp130 signaling system to induce $R E G$ I $\alpha$ gene expression.

\section{Anti-REG I $\alpha$ Autoantibodies}

\subsection{Detection of Anti-REG Ia Autoantibodies in Primary Sjögren's Syndrome Patient Sera}

Autoantibodies against REG I $\alpha$ protein (Anti-REG I $\alpha$ autoantibodies) have been detected by Western blot as described [13,62,71,72]. Briefly, recombinant human REG I $\alpha$ protein $(20 \mu \mathrm{g})$ [62] was electrophoresed on a $12.5 \%$ sodium dodecyl sulfate-polyacrylamide gel $(9 \times 7 \times 0.1 \mathrm{~cm})$ with a constant current at $20 \mathrm{~mA} / \mathrm{gel}$ for $100 \mathrm{~min}$ and electrotransferred onto a polyvinylidene difluoride membrane using a semidry electroblotter [62,71,73]. After blocking with 5\% non-fat dry milk, the membrane was incubated with patient or control serum, which had been diluted 1024-fold with 5\% non-fat dry milk, using a screener blotter [61,71,73]. The membrane was then rinsed with phosphate-buffered saline containing $0.1 \%$ Tween 20 and incubated with goat anti-human IgG labeled with horseradish peroxidase at 1/1600 dilution. The signals were visualized using an enhanced 
chemiluminescent detection system, as described previously [62,71,73]. The band intensities from positive blots were analyzed, and the density was standardized using the value of an internal control sample as a relative value $[62,71,73]$.

The sera from 117 patients with pSS and 271 controls were screened for anti-REG I $\alpha$ antibody [13]. The relative anti-REG I $\alpha$ antibody values for all controls, with the exception of six individuals, were within the mean $\pm 3 \mathrm{SD}$ value. Henceforth, we treated this mean $\pm 3 \mathrm{SD}$ value of the controls as the cut-off value for all related data analyses. Eleven percent (13 of 117) of patients with pSS tested positive for anti-REG I $\alpha$ antibody, whereas only $2.2 \%$ (six out of 271 ) were positive in the controls.

\subsection{The Role of Anti-REG Ia Autoantibodies in Hyposalivation of Primary Sjögren's Syndrome}

We evaluated the correlation between anti-REG I $\alpha$ antibody and the clinicopathological factors of pSS patients [13]. The anti-REG I $\alpha$ antibody-positive group showed significantly lower saliva secretion than the negative group using the unstimulated Saxon test. The Saxon test for xerostomia involves chewing on a folded sterile sponge for $2 \mathrm{~min}$, and saliva production is quantified by weighing the sponge before and after chewing [74]. The ratio of a destructive stage (stage 4, based on Rubin and Holt's criteria) in sialography in the anti-REG I $\alpha$ antibody-positive group was significantly higher than that in the anti-REG I $\alpha$ antibody-negative group. In the patients with pSS, no correlation was found in age, sex ratio, serum levels of SS-A/SS-B autoantibody, anti-nuclear antibody titer, rheumatoid factor, amylase, $\mathrm{IgG}$, and $\mathrm{HbA1c}$ between the anti-REG I $\alpha$ antibody-positive group and the anti-REG I $\alpha$ antibody-negative group. There was no significant difference between the two groups in the occurrence of kerato-conjunctivitis sicca, as determined by Schirmer's test. In terms of the histological features of the labial salivary gland biopsy according to Greenspan's grade, there was no significant difference in the anti-REG I $\alpha$ antibody-positive and the anti-REG I $\alpha$ antibody-negative groups. We also examined extraglandular disease, systemic or severe (skin rash, Raynaud's phenomenon, arthralgia, thyroid gland disease, interstitial pneumonia, primary biliary cirrhosis, renal tubular acidosis, peripheral neuropathy, and lymphoma), finding no significant difference between the two groups.

The anti-REG I $\alpha$ antibody-positive group showed significantly lower salivary secretion and a higher ratio of the destructive stage in sialography. REG I $\alpha$ protein was expressed in MSG ductal epithelial cells in nearly half of the pSS patients, and in MSG acinar cells in some. Interestingly, all the patients in the anti-REG I $\alpha$ antibody-positive group showed REG I $\alpha$ expression in MSG ductal cells, whereas only $40 \%$ in the anti-REG I $\alpha$ antibody-negative group showed REG I $\alpha$ expression in MSG. These results suggest that autoimmunity to REG is associated with the regeneration of the ductal epithelial cells of MSG in pSS patients.

When salivary glands are damaged by inflammation, the REG I $\alpha$ protein may be induced in progenitor cells for MSG ductal/acinar cells, such as ductal cells, to recover damaged cell mass by regeneration. Accumulating evidence concerning the development of the salivary gland suggests that the stem cell population of salivary glands is present in the intercalated duct $[75,76]$. Recently, it was reported that salivary gland homeostasis is maintained through acinar cell self-duplication, and acinar cells surviving injury are involved in the generation of salivary glands [77]. Additionally, the proliferation of pancreatic $\beta$ cells has been reported to be attenuated by the diabetic patient sera containing anti-REG I $\alpha$ antibody in vitro [62]. It is quite possible that the anti-REG I $\alpha$ antibody attenuates not only the growth-promoting effects of REG to fully differentiated acinar/ductal cells but 
also the regeneration of the stem cell population of salivary glands. As a result, salivary functions including saliva secretion could become worse in pSS patients with anti-REG I $\alpha$ antibody (Figure 1) [78].

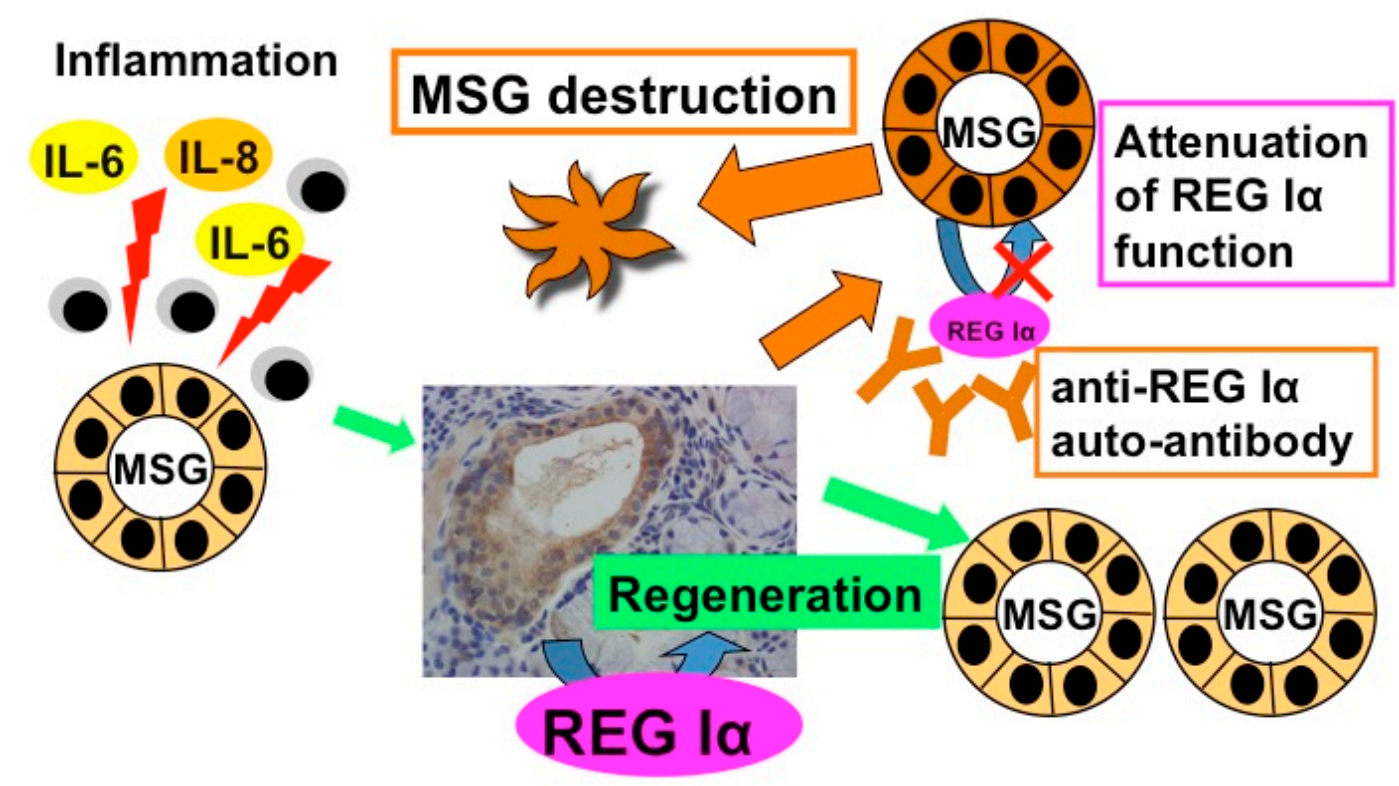

Figure 1. Possible role of anti-REG I $\alpha$ auto-antibody in MSG destruction in SS (adopted from [78]). The expression of REG I $\alpha$ in MSG of SS was significantly higher than that of the control, and the saliva secretion was significantly low in SS patients with anti-REG I $\alpha$ auto-antibody [13]. These results strongly suggest that autoimmunity to REG I $\alpha$ is associated with the tissue injury of salivary glands in at least some SS patients. When salivary glands are damaged by inflammation, REG I $\alpha$ protein is induced in acinar progenitor cells, such as ductal cells, to recover damaged cell mass by regeneration. In the presence of anti-REG I $\alpha$ auto-antibodies, ductal epithelial cell regeneration by REG I $\alpha$ protein is attenuated, and REG I $\alpha$-producing ductal epithelial cell are destructed by the antibodies. As a result, salivary function goes worse in SS patients with anti-REG I $\alpha$ auto-antibodies.

Hyposalivation is an important clinical concern in oral health and is known to induce various problems including dental caries, periodontitis, denture problems, mastication and swallowing problems, burning sensations, and dysgeusia [79]. Muscarinic agonist medications such as pilocarpine and cevimeline induced salivary secretion from the residual functional tissue [80]. However, these medications provided temporary relief of symptoms and have a limited effect on the recovery of damaged tissues. Accordingly, the development of a novel treatment to restore or regenerate damaged salivary gland tissues is eagerly awaited. It is unclear whether a specific signal is required for the regeneration of salivary glands. REG I $\alpha$ may be a candidate growth factor for the regeneration of the salivary gland cells as hepatocyte growth factor is a well-known protein that promotes the regeneration of liver tissue and even protects tissue from damages [81-83]. Therefore, it is expected that the regenerative growth of ductal epithelial cells will provide a practical therapeutic approach for SS.

In the aspects of SS diagnosis, the detection of anti-REG I $\alpha$ antibody is not so powerful. However, considering the correlation between the salivary functions and the existence of serum anti-REG I $\alpha$ antibody, detection of the anti-REG I $\alpha$ could be a useful diagnostic marker for the prognosis of 
salivary functions such as saliva secretion. In addition, very small volumes of serum (less than $1 \mu \mathrm{L})$ are required to detect the anti-REG $\mathrm{I} \alpha$ antibody $[13,62]$.

\section{Gene Expression of REG I $\alpha$ as an Auto-Antigen}

As mentioned, the mRNA levels of $I L-6$ and $I L-8$ in the MSG of pSS patients are significantly increased compared to those in normal MSG [13], suggesting that these cytokines may be involved in the overexpression of REG I $\alpha$ mRNA in the pSS MSG. To investigate whether IL-6 or IL-8 upregulate REG I $\alpha$, we analyzed the REG I $\alpha$ mRNA expression in human NS-SV-DC salivary ductal cells [84] via qRT-PCR. Treatment with IL-6 but not IL-8 or dexamethasone (Dx) induced the expression of REG I $\alpha$ mRNA [85]. The combination of IL-6+Dx or IL-6+IL-8 showed no additional effect compared to IL-6 alone. These results indicate that salivary ductal cells express REG I $\alpha$ mRNA in response to the stimulation of IL-6.

To determine whether the increase of REG I $\alpha$ mRNA was caused by the activation of transcription, a 1216-bp fragment containing 1190-bp of the promoter region of the human REG I $\alpha$ gene was fused to the luciferase gene and transfected into human NS-SV-DC and rat A5 [86,87] salivary ductal cells. We found that IL-6 stimulation significantly enhanced the REG I $\alpha$ promoter activity not only in NS-SV-DC cells but also in A5 cells. Treatment with IL-8 did not change the transcriptional activity of $R E G I \alpha$ [85]. These results revealed that REG I $\alpha$ mRNA was induced by IL-6 in salivary ductal cells at the transcriptional level.

In order to identify the region essential for the transcription of the REG I $\alpha$ mRNA by IL-6, progressive deletion of the $R E G I \alpha$ promoter was performed. The deletion down to position -141 did not attenuate IL-6-induced REG I $\alpha$ promoter activity; however, an additional deletion to -117 caused a remarkable decrease in the IL-6-induced promoter activity of REG I [85]. These results indicated that the promoter region of -141 to -117 of the $R E G I \alpha$ gene was responsible for the $R E G I \alpha$ promoter activation in salivary ductal cells by IL-6.

A computer-aided search for sequences similar to known cis-acting elements revealed that the region of -141 to -117 of the REG I $\alpha$ gene contains consensus-binding sequences for STAT. In order to verify the role of STAT3 in IL-6-induced REG I $\alpha$ induction, small interfering RNA (siRNA) for human STAT3 mRNA was introduced into NS-SV-DC cells, and IL-6-induced REG I $\alpha$ mRNA expression was analyzed by qRT-PCR. The introduction of siRNA for human STAT3 abolished not only IL-6-induced STAT3 upregulation but also IL-6-induced REG I $\alpha$ upregulation [85].

Taken together, our findings demonstrate that $R E G I \alpha$ overexpression in salivary ductal cells is induced by IL- 6 but not by IL- 8 at the transcriptional level, and this IL- 6 stimulation enhanced REG I $\alpha$ gene expression through STAT3 activation. IL-6, a potent proinflammatory cytokine, is involved in acute phase response, B cell proliferation and plasma cell formation, and $\mathrm{T}$ cell stimulation and recruitment [54]. The serum concentrations of IL-6 were found to be high in pSS patients as well as in NOD mice [44] and rat autoimmune myocarditis models [88], and the levels of IL-6 concentration correlated with the degree of infiltration of lymphocytes in the salivary gland [89-91]. Furthermore, autoimmunity against Reg has been reported in NOD mice [92] and human diabetic patients [62]. Binding of IL-6 to the receptor leads to homodimerization of an IL-6 receptor component, gp130, which results in the activation of JAK and subsequent phosphorylation of STAT3 [54]. 
STAT3 plays a central role in transmitting cytokine signals to the nucleus and promotes cell proliferation and anti-apoptosis [56-59]. Furthermore, accumulating evidence indicates that the JAK/STAT pathway may be involved in multiple immune functions: STAT1 and STAT4 mainly induce IFN $\gamma$ expression in Th1 cells, STAT6 induces IL-4 expression in Th2 cells, and STAT3 induces IL-17 expression in Th17 cells [93]. For example, an orally available JAK inhibitor, tofacitinib, has demonstrated efficacy and safety in rheumatoid arthritis, which is a representative autoimmune disease characterized by systemic inflammatory synovitis [94,95].

$R E G I \alpha$ transcription in salivary ductal cells was stimulated by IL-6. STAT3 bound the consensus sequence in the REG I $\alpha$ promoter and regulated transcription in ductal epithelial cells in response to IL-6 stimulation. This IL-6/STAT pathway and IL-6/STAT-dependent REG I $\alpha$ induction in salivary ductal cells may play a role in the pathogenesis of pSS (Figure 2) [85].

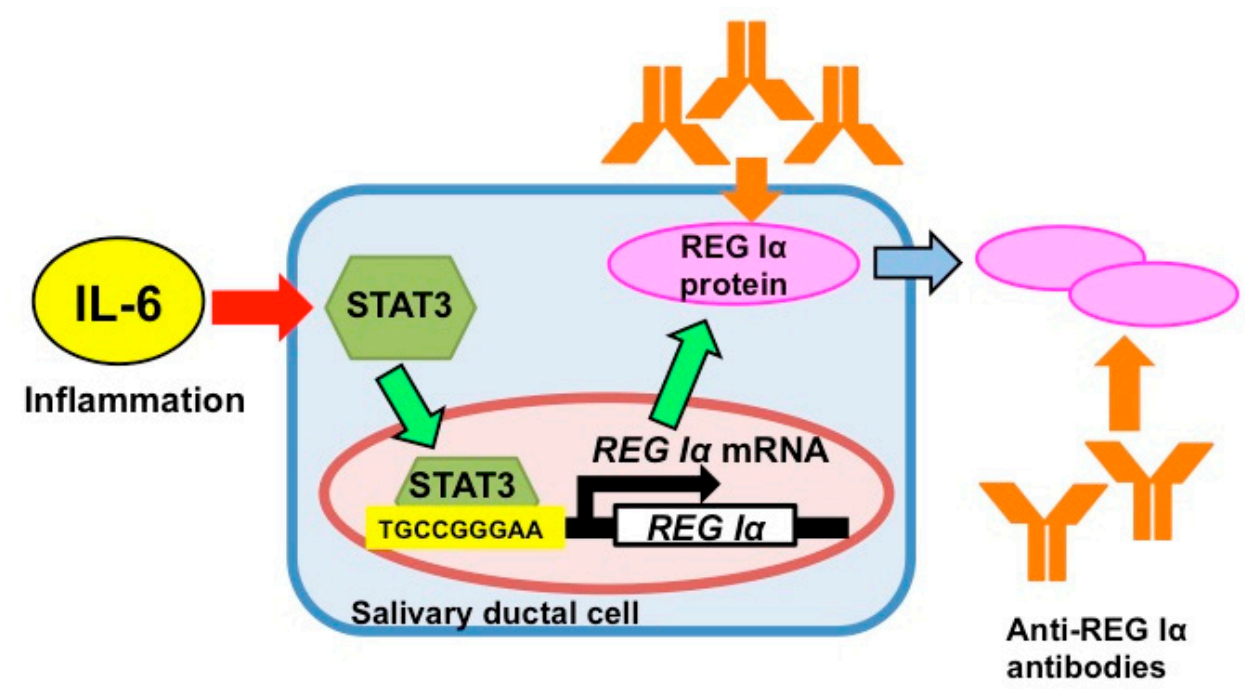

Figure 2. Possible mechanism of the IL-6-induced REG I $\alpha$ expression in salivary ductal cells (adopted from [85]). REG I $\alpha$ was overexpressed in salivary ductal cells of patients with Sjögren's syndrome [13]. IL-6 stimulation enhanced the $R E G I \alpha$ gene transcription in salivary ductal cells via STAT3 activation.

\section{Conclusions}

The pathogenesis of SS remains elusive. Environmental, genetic, and hormonal factors may be involved (especially as the role of trigger), and in the past researchers have focused on the immune responses, especially $\mathrm{T}$ cell-mediated and humoral immunities in the histopathological lesion during the inflammatory phase of SS [96]. This review contributes by revealing new aspects of the mechanisms mediated by a novel autoantigen relating to the dysfunction of salivary glands.

It has been suggested that a genetic defect in the production of neurotransmitters may underlie the pathogenesis of saliva insufficiency [97]. In addition, exogenous environmental factors (viruses and bacteria) may activate innate immunity, resulting in the productions of type I IFN and complements. Circulating proinflammatory cytokines may induce not only dysfunction but also morphological changes at the ultrastructural level of salivary glands. The cumulative effects of each factor/change may induce the decreased function of salivary glands without inflammation. 
We stressed the possible involvement of the Reg gene and its product as an autoantigen in the regeneration and destruction of salivary gland cells in pSS. We focused on how the salivary gland dysfunction is initiated and maintained and how mediation by Reg gene and Reg protein contributes to its regeneration or progression. We have shown that REG I $\alpha$ mRNA is overexpressed in the pSS patient salivary glands and that REG I $\alpha$ protein is expressed in the ductal epithelial cells of MSGs in patients with pSS. Furthermore, we have demonstrated that $R E G I \alpha$ transcription in salivary ductal cells is stimulated by IL-6, and that STAT3 binds the consensus sequence of REG I $\alpha$ promoter and regulated transcription in response to IL-6 stimulation.

Importantly, salivary secretion was reduced in pSS patients with anti-REG I $\alpha$ antibody. There was also a correlation between the presence of anti-REG I $\alpha$ antibody and REG I $\alpha$ protein expression in the ductal cells of MSG. Autoimmunity to REG I $\alpha$ could play an important role in the regeneration of MSG ductal epithelial cells in pSS. The IL-6/STAT-dependent REG I $\alpha$ induction in ductal cells may act in concert with the pathogenesis of pSS. The causes of hypofunction in salivary glands are complex. The future challenge is to distinguish nonimmunologic mechanisms from immunologic mechanisms in target organs in this unique disease.

\section{Acknowledgments}

The authors would like to thank Yoshiko Dohi, Hiroki Tsujinaka, and Yasuhito Tanaka for valuable discussion, and Tomoko Miyaoka, Sumiyo Sakuramoto-Tsuchida, and Saori Kondo for their kind help. This work was funded in part by Grants-in-Aid for Scientific Research from the Ministry of Education, Culture, Sports, Science, and Technology, Japan (Grant nos. 22591096 and 23659161), and the Japan Science and Technology Agency.

\section{Author Contributions}

Takashi Fujimoto wrote the manuscript and designed the figures. Kiyomi Yoshimoto, Takanori Fujimura, Maiko Takeda, Akiyo Yamauchi, Asako Itaya-Hironaka, and Shin Takasawa reviewed and revised the manuscript.

\section{Conflicts of Interest}

The authors declare no conflict of interest.

\section{References}

1. Anaya, J.M.; Talal, N. Arthritis and Allied Conditions. In A Textbook of Rheumatology, 13th ed.; Koopman, W.J., Ed.; Williams \& Wilkins: Baltimore, MD, USA, 1997; pp. 1561-1580.

2. Alamanos, Y.; Tsifetaki, N.; Voulgari, P.V.; Venetsanopoulou, A.I.; Siozos, C.; Drosos, A.A. Epidemiology of primary Sjögren's syndrome in north-west Greece, 1982-2003. Rheumatology (Oxford) 2006, 45, 187-191.

3. Trontzas, P.I.; Andrianakos, A.A. Sjögren's syndrome: A population based study of prevalence in Greece. The ESOrDIG study. Ann. Rheum. Dis. 2005, 64, 1240-1241. 
4. Bowman, S.J.; Ibrahim, G.H.; Holmes, G.; Hamburger, J.; Ainsworth, J.R. Estimating the prevalence among Caucasian women of primary Sjögren's syndrome in two general practices in Birmingham, UK. Scand. J. Rheumatol. 2004, 33, 39-43.

5. Delaleu, N.; Jonsson, M.V.; Appel, S.; Jonsson, R. New concepts in the pathogenesis of Sjögren's syndrome. Rheum. Dis. Clin. North Am. 2008, 34, 833-845.

6. Venables, P.J. Sjögren's syndrome. Best Pract. Res. Clin. Rheumatol. 2004, 18, 313-329.

7. Ramos-Casals, M.; Loustaud-Ratti, V.; De Vita, S.; Zeher, M.; Bosch, J.A.; Toussirot, E.; Medina, F.; Rosas, J.; Anaya, J.M.; Font, J. SS-HCV Study Group. Sjögren syndrome associated with hepatitis C virus: A multicenter analysis of 137 cases. Medicine (Baltimore) 2005, 84, 81-89.

8. Terazono, K.; Yamamoto, H.; Takasawa, S.; Shiga, K.; Yonemura, Y.; Tochino, Y.; Okamoto, H. A novel gene activated in regenerating islets. J. Biol. Chem. 1988, 263, 2111-2114.

9. Okamoto, H.; Takasawa, S. Recent advances in the Okamoto model: The CD38-cyclic ADP-ribose signal system and the regenerating gene protein (Reg)-Reg receptor system in $\beta$-cells, Diabetes 2002, 51, S462-S473.

10. Takasawa, S. Regenerating gene (REG) product and its potential clinical usage. Expert Opin. Ther. Targets 2015, in press.

11. Zhang, Y.W.; Ding, L.S.; Lai, M.D. Reg gene family and human diseases. World J. Gastroenterol. 2003, 9, 2635-2641.

12. Ota, H.; Takasawa, S.; Yamauchi, M.; Yoshikawa, M.; Tomoda, K.; Kimura, H. Intermittent hypoxia in pancreatic $\beta$ cells. Pancreat. Diasord. Ther. 2015, S5, 004.

13. Yoshimoto, K.; Fujimoto, T.; Itaya-Hironaka, A.; Miyaoka, T.; Sakuramoto-Tsuchida, S.; Yamauchi, A.; Takeda, M.; Kasai, T.; Nakagawara, K.; Nonomura, A.; et al. Involvement of autoimmunity to REG, a regeneration factor, in patients with primary Sjögren's syndrome. Clin. Exp. Immunol. 2013, 174, 1-9.

14. Katsifis, G.E.; Moutsopoulos, N.M.; Wahl, S.M. T lymphocytes in Sjögren's syndrome: Contributors to and regulators of pathophysiology. Clin. Rev. Allergy Immunol. 2007, 32, 252-264.

15. Manoussakis, M.N.; Boiu, S.; Korkolopoulou, P.; Kapsogeorgou, E.K.; Kavantzas, N.; Ziakas, P.; Patsouris, E.; Moutsopoulos, H.M. Rates of infiltration by macrophages and dendritic cells and expression of interleukin-18 and interleukin-12 in the chronic inflammatory lesions of Sjögren's syndrome: correlation with certain features of immune hyperactivity and factors associated with high risk of lymphoma development. Arthritis Rheum. 2007, 56, 3977-3988.

16. Moutsopoulos, H.M. Sjögren's syndrome: Autoimmune epithelitis. Clin. Immunol. Immunopathol. 1994, 72, 162-165.

17. Vitali, C.; Bombardieri, S.; Jonsson, R.; Moutsopoulos, H.M.; Alexander, E.L.; Carsons, S.E.; Daniels, T.E.; Fox, P.C.; Fox, R.I.; Kassan, S.S.; et al. Classification criteria for Sjögren's syndrome: A revised version of the European criteria proposed by the American-European Consensus Group. Ann. Rheum. Dis. 2002, 61, 554-558.

18. Mavragani, C.P.; Moutsopoulos, H.M. The geoepidemiology of Sjögren's syndrome. Autoimmun. Rev. 2010, 9, A305-A310.

19. Mitsias, D.I.; Kapsogeorgou, E.K.; Moutsopoulos, H.M. Sjögren's syndrome: Why autoimmune epithelitis? Oral Dis. 2006, 12, 523-532. 
20. Soyfoo, M.S.; Steinfeld, S.; Delporte, C. Usefulness of mouse models to study the pathogenesis of Sjögren's syndrome. Oral Dis. 2007, 13, 366-375.

21. Cha, S.; Peck, A.B.; Humphreys-Beher, M.G. Progress in understanding autoimmune exocrinopathy using the nonobese diabetic mouse: An update. Crit. Rev. Oral Biol. Med. 2002, 13, 5-16.

22. Robinson, C.P.; Cornelius, J.; Bounous, D.E.; Yamamoto, H.; Humphreys-Beher, M.G.; Peck, A.B. Characterization of the changing lymphocyte populations and cytokine expression in the exocrine tissues of autoimmune NOD mice. Autoimmunity 1998, 27, 29-44.

23. Humphreys-Beher, M.G.; Brayer, J.; Yamachika, S.; Peck, A.B.; Jonsson, R. An alternative perspective to the immune response in autoimmune exocrinopathy: Induction of functional quiescence rather than destructive autoaggression. Scand. J. Immunol. 1999, 49, 7-10.

24. Talal, N.; Sylvester, R.A.; Daniels, T.E.; Greenspan, J.S.; Williams, R.C., Jr. T and B lymphocytes in peripheral blood and tissue lesions in Sjögren's syndrome. J. Clin. Invest. 1974, 53, 180-189.

25. Christodoulou, M.I.; Kapsogeorgou, E.K.; Moutsopoulos, N.M.; Moutsopoulos, H.M. Foxp3+ T-regulatory cells in Sjogren's syndrome: Correlation with the grade of the autoimmune lesion and certain adverse prognostic factors. Am. J. Pathol. 2008, 173, 1389-1396.

26. Katsifis, G.E.; Rekka, S.; Moutsopoulos, N.M.; Pillemer, S.; Wahl, S.M. Systemic and local interleukin-17 and linked cytokines associated with Sjögren's syndrome immunopathogenesis. Am. J. Pathol. 2009, 175, 1167-1177.

27. Espinosa, A.; Dardalhon, V.; Brauner, S.; Ambrosi, A.; Higgs, R.; Quintana, F.J.; Sjöstrand, M.; Eloranta, M.L.; Ní Gabhann, J.; Winqvist, O.; et al. Loss of the lupus autoantigen Ro52/Trim21 induces tissue inflammation and systemic autoimmunity by disregulating the IL-23-Th17 pathway. J. Exp. Med. 2009, 206, 1661-1671.

28. Sakai, A.; Sugawara, Y.; Kuroishi, T.; Sasano, T.; Sugawara, S. Identification of IL-18 and Th17 cells in salivary glands of patients with Sjögren's syndrome, and amplification of IL-17-mediated secretion of inflammatory cytokines from salivary gland cells by IL-18. J. Immunol. 2008, 181, 2898-2906.

29. Nguyen, C.Q.; Hu, M.H.; Li, Y.; Stewart, C.; Peck, A.B. Salivary gland tissue expression of interleukin-23 and interleukin-17 in Sjögren's syndrome: Findings in humans and mice. Arthritis Rheum. 2008, 58, 734-743.

30. Fox, R.I.; Kang, H.I. Pathogenesis of Sjögren's syndrome. Rheum. Dis. Clin. North. Am. 1992, 18, 517-538.

31. Haneji, N.; Hamano, H.; Yanagi, K.; Hayashi, Y. A new animal model for primary Sjögren's syndrome in NFS/sld mutant mice. J. Immunol. 1994, 153, 2769-2777.

32. Kino-Ohsaki, J.; Nishimori, I.; Morita, M.; Okazaki, K.; Yamamoto, Y.; Onishi, S.; Hollingsworth, M.A. Serum antibodies to carbonic anhydrase I and II in patients with idiopathic chronic pancreatitis and Sjögren's syndrome. Gastroenterology 1996, 110, 1579-1586.

33. Bacman, S.R.; Berra, A.; Sterin-Borda, L.; Borda, E.S. Human primary Sjögren's syndrome autoantibodies as mediators of nitric oxide release coupled to lacrimal gland muscarinic acetylcholine receptors. Curr. Eye Res. 1998, 17, 1135-1142.

34. Bacman, S.; Sterin-Borda, L.; Camusso, J.J.; Arana, R.; Hubscher, O.; Borda, E. Circulating antibodies against rat parotid gland M3 muscarinic receptors in primary Sjögren's syndrome. Clin. Exp. Immunol. 1996, 104, 454-459. 
35. Warnock, M.G.; Goodacre, J.A. Cryptic T-cell epitopes and their role in the pathogenesis of autoimmune diseases. Br. J. Rheumatol. 1997, 36, 1144-1150.

36. Watanabe, T.; Yonemura, Y.; Yonekura, H.; Suzuki, Y.; Miyashita, H.; Sugiyama, K.; Moriizumi, S.; Unno, M.; Tanaka, O.; Kondo, H.; et al. Pancreatic beta-cell replication and amelioration of surgical diabetes by Reg protein. Proc. Natl. Acad. Sci. USA 1994, 91, 3589-3592.

37. Watanabe, T.; Yonekura, H.; Terazono, K.; Yamamoto, H.; Okamoto, H. Complete nucleotide sequence of human reg gene and its expression in normal and tumoral tissues. The reg protein, pancreatic stone protein, and pancreatic thread protein are one and the same product of the gene. J. Biol. Chem. 1990, 265, 7432-7439.

38. Moriizumi, S.; Watanabe, T.; Unno, M.; Nakagawara, K.; Suzuki, Y.; Miyashita, H.; Yonekura, H.; Okamoto, H. Isolation, structural determination and expression of a novel reg gene, human reg I $\beta$. Biochim. Biophys. Acta 1994, 1217, 199-202.

39. Nata, K.; Liu, Y.; Xu, L.; Ikeda, T.; Akiyama, T.; Noguchi, N.; Kawaguchi, S.; Yamauchi, A.; Takahashi, I.; Shervani, N.J.; et al. Molecular cloning, expression and chromosomal localization of a novel human REG family gene, REG III. Gene 2004, 340, 161-170.

40. Lasserre, C.; Christa, L.; Simon, M.T.; Vernier, P.; Bréchot, C. A novel gene (HIP) activated in human primary liver cancer. Cancer Res. 1992, 52, 5089-5095.

41. Orelle, B.; Keim, V.; Masciotra, L.; Dagorn, J.C.; Iovanna, J.L. Human pancreatitis-associated protein. Messenger RNA cloning and expression in pancreatic diseases. J. Clin. Invest. 1992, 90, 2284-2291.

42. Hartupee, J.C.; Zhang, H.; Bonaldo, M.F.; Soares, M.B.; Dieckgraefe, B.K. Isolation and characterization of a cDNA encoding a novel member of the human regenerating protein family: Reg IV. Biochim. Biophys. Acta 2001, 1518, 287-293.

43. Unno, M.; Yonekura, H.; Nakagawara, K.; Watanabe, T.; Miyashita, H.; Moriizumi, S.; Okamoto, H.; Itoh, T.; Teraoka, H. Structure, chromosomal localization, and expression of mouse reg genes, reg I and reg II. A novel type of reg gene, reg II, exists in the mouse genome. J. Biol. Chem. 1993, 268, 15974-15982.

44. Planas, R.; Alba, A.; Carrillo, J.; Puertas, M.C.; Ampudia, R.; Pastor, X.; Okamoto, H.; Takasawa, S.; Gurr, W.; Pujol-Borrell, R.; et al. Reg (regenerating) gene overexpression in islets from non-obese diabetic mice with accelerated diabetes: Role of IFN $\beta$. Diabetologia 2006, 49, 2379-2387.

45. Livesey, F.J.; O'Brien, J.A.; Li, M.; Smith, A.G.; Murphy, L.J.; Hunt, S.P. A Schwann cell mitogen accompanying regeneration of motor neurons. Nature 1997, 390, 614-618.

46. Nishimune, H.; Vasseur, S.; Wiese, S.; Birling, M.C.; Holtmann, B.; Sendtner, M.; Iovanna, J.L.; Henderson, C.E. Reg-2 is a motoneuron neurotrophic factor and a signalling intermediate in the CNTF survival pathway. Nat. Cell Biol. 2000, 2, 906-914.

47. Kimura, T.; Fukui, H.; Sekikawa, A.; Yamagishi, H.; Ichikawa, K.; Tomita, S.; Fujii, S.; Imura, J.; Kawamata, H.; Chiba, T.; et al. Involvement of REG I $\alpha$ protein in the regeneration of ductal epithelial cells in the minor salivary glands of patients with Sjögren's syndrome. Clin. Exp. Immunol. 2009, 155, 16-20. 
48. Akiyama, T.; Takasawa, S.; Nata, K.; Kobayashi, S.; Abe, M.; Shervani, N.J.; Ikeda, T.; Nakagawa, K.; Unno, M.; Matsuno, S.; et al. Activation of Reg gene, a gene for insulin-producing $\beta$-cell regeneration: poly(ADP-ribose) polymerase binds Reg promoter and regulates the transcription by autopoly(ADP-ribosyl)ation. Proc. Natl. Acad. Sci. USA 2001, 98, 48-53.

49. Kazumori, H.; Ishihara, S.; Hoshino, E.; Kawashima, K.; Moriyama, N.; Suetsugu, H.; Sato, H.; Adachi, K.; Fukuda, R.; Watanabe, M.; et al. Neutrophil chemoattractant $2 \beta$ regulates expression of the Reg gene in injured gastric mucosa in rats. Gastroenterology 2000, 119, 1610-1622.

50. Yoshino, N.; Ishihara, S.; Rumi, M.A.; Ortega-Cava, C.F.; Yuki, T.; Kazumori, H.; Takasawa, S.; Okamoto, H.; Kadowaki, Y.; Kinoshita, Y. Interleukin-8 regulate expression of Reg protein in Helicobacter pylori-infected gastric mucosa. Am. J. Gastroenterol. 2005, 100, 2157-2166.

51. Lee, K.S.; Kalantzis, A.; Jackson, C.B.; O’Connor, L.; Murata-Kamiya, N.; Hatakeyama, M.; Judd, L.M.; Giraud, A.S.; Menheniott, T.R. Helicobacter pylori CagA triggers expression of the bactericidal lectin REG3 $\gamma$ via gastric STAT3 activation. PLOS ONE 2012, 7, e30786.

52. Sekikawa, A.; Fukui, H.; Suzuki, K.; Karibe, T.; Fujii, S.; Ichikawa, K.; Tomita, S.; Imura, J.; Shiratori, K.; Chiba, T.; et al. Involvement of the IL-22/REG I $\alpha$ axis in ulcerative colitis. Lab. Invest. 2010, 90, 496-505.

53. Sekikawa, A.; Fukui, H.; Fujii, S.; Nanakin, A.; Kanda, N.; Uenoyama, Y.; Sawabu, T.; Hisatsune, H.; Kusaka, T.; Ueno, S.; et al. Possible role of REG I $\alpha$ protein in ulcerative colitis and colitic cancer. Gut 2005, 54, 1437-1444.

54. Roescher, N.; Tak, P.P.; Illei, G.G. Cytokines in Sjögren's syndrome: Potential therapeutic targets. Ann. Rheum. Dis. 2010, 69, 945-948.

55. Hirano, T.; Ishihara, K.; Hibi, M. Roles of STAT3 in mediating the cell growth, differentiation and survival signals relayed through the IL-6 family of cytokine receptors. Oncogene 2000, 19, 2548-2556.

56. Bromberg, J. Stat proteins and oncogenesis. J. Clin. Invest. 2002, 109, 1139-1142.

57. Grandis, J.R.; Drenning, S.D.; Zeng, Q.; Watkins, S.C.; Melhem, M.F.; Endo, S.; Johnson, D.E.; Huang, L.; He, Y.; Kim, J.D. Constitutive activation of Stat3 signaling abrogates apoptosis in squamous cell carcinogenesis in vivo. Proc. Natl. Acad. Sci. USA 2000, 97, 4227-4232.

58. Song, J.I.; Grandis, J.R. STAT signaling in head and neck cancer. Oncogene 2000, 19, 2489-2495.

59. Rahaman, S.O.; Harbor, P.C.; Chernova, O.; Barnett, G.H.; Vogelbaum, M.A.; Haque, S.J. Inhibition of constitutively active Stat3 suppresses proliferation and induces apoptosis in glioblastoma multiforme cells. Oncogene 2002, 21, 8404-8413.

60. Sekikawa, A.; Fukui, H.; Fujii, S.; Ichikawa, K.; Tomita, S.; Imura, J.; Chiba, T.; Fujimori, T. REG I $\alpha$ protein mediates an anti-apoptotic effect of STAT3 signaling in gastric cancer cells. Carcinogenesis 2008, 29, 76-83.

61. Yamauchi, A.; Itaya-Hironaka, A.; Sakuramoto-Tsuchida, S.; Takeda, M.; Yoshimoto, K.; Miyaoka, T.; Fujimura, T.; Tsujinaka, H.; Tsuchida, C.; Ota, H.; et al. Synergistic activations of REG I $\alpha$ and $R E G$ I $\beta$ promoters by IL-6 and glucocorticoids through JAK/STAT pathway in human pancreatic $\beta$ cells. J. Diabetes Res. 2015, 2015, 173058.

62. Shervani, N.J.; Takasawa, S.; Uchigata, Y.; Akiyama, T.; Nakagawa, K.; Noguchi, N.; Takada, H.; Takahashi, I.; Yamauchi, A.; Ikeda, T.; et al. Autoantibodies to REG, a beta-cell regeneration factor, in diabetic patients. Eur. J. Clin. Invest. 2004, 34, 752-758. 
63. Astorri, E.; Guglielmi, C.; Bombardieri, M.; Alessandri, C.; Buzzetti, R.; Maggi, D.; Velesini, G.; Pitzalis, C.; Pozzilli, P. Circulating Reg1 $\alpha$ proteins and autoantibodies to Reg1 $\alpha$ proteins as biomarkers of $\beta$-cell regeneration and damage in type 1 diabetes. Horm. Metab. Res. 2010, 42, 955-960.

64. Kiji, T.; Dohi, Y.; Nishizaki, K.; Takasawa, S.; Okamoto, H.; Nagasaka, S.; Naito, H.; Yonemasu, K.; Taniguchi, S. Enhancement of cell viability in cryopreserved rat vascular grafts by administration of regenerating gene (Reg) inducers. J. Vasc. Res. 2003, 40, 132-139.

65. Zenilman, M.E.; Magnuson, T.H.; Perfetti, R.; Chen, J.; Shuldiner, A.R. Pancreatic reg gene expression is inhibited during cellular differentiation. Ann. Surg. 1997, 225, 327-332.

66. Qiu, L.; List, E.O.; Kopchick, J.J. Differentially expressed proteins in the pancreas of diet-induced diabetic mice. Mol. Cell. Proteomics 2005, 4, 1311-1318.

67. Grisius, M.M.; Bermudez, D.K.; Fox, P.C. Salivary and serum interleukin 6 in primary Sjögren's syndrome. J. Rheumatol. 1997, 24, 1089-1091.

68. Badillo-Almaraz, I.; Avalos-Diaz, E.; Villalobos-Hurtado, R.; Herrera-Esparza, R. FasL and Bax genes are differentially expressed in acinar epithelium and inflammatory cells of primary Sjögren salivary glands. Minerva Med. 2003, 94, 341-345.

69. Lee, Y.J.; Scofield, R.H.; Hyon, J.Y.; Yun, P.Y.; Lee, H.J.; Lee, E.Y.; Lee, E.B.; Song, Y.W. Salivary chemokine levels in patients with primary Sjögren's syndrome. Rheumatology (Oxford) 2010, 49, 1747-1752.

70. Sekikawa, A.; Fukui, H.; Fuji, S.; Nanakin, A.; Nakada, N.; Uenoyama, Y.; Sawabu, T.; Hisatsune, H.; Kusaka, T.; Ueno, S.; et al. Possible role of REG I $\alpha$ protein in ulcerative colitis and colitic cancer. Gut 2005, 54, 1437-1444.

71. Ikehata, F.; Satoh, J.; Nata, K.; Tohgo, A.; Nakazawa, T.; Kato, I.; Kobayashi, S.; Akiyama, T.; Takasawa, S.; Toyota, T.; et al. Autoantibodies against CD38 (ADP-ribosyl cyclase/cyclic ADP-ribose hydrolase) that impair glucose-induced insulin secretion in noninsulin-dependent diabetes patients. J. Clin. Invest. 1998, 102, 395-401.

72. Pupilli, C.; Giannini, S.; Marchetti, P.; Lupi, R.; Antonelli, A.; Malavasi, F.; Takasawa, S.; Okamoto, H.; Ferrannini, E. Autoantibodies to CD38 (ADP-ribosyl cyclase/cyclic ADP-ribose hydrolase) in Caucasian patients with diabetes: Effects on insulin release from human islets. Diabetes 1999, 48, 2309-2315.

73. Antonelli, A.; Fallahi, P.; Nesti, C.; Pupilli, C.; Marchetti, P.; Takasawa, S.; Okamoto, H.; Ferrannini, E. Anti-CD38 autoimmunity in patients with chronic autoimmune thyroiditis or Graves' disease. Clin. Exp. Immunol. 2001, 126, 426-431.

74. Kohler, P.F.; Winter, M.E. A quantitative test for xerostomia. The Saxon test, an oral equivalent of the Schirmer test. Arthritis Rheum. 1985, 28, 1128-1132.

75. Man, Y.G.; Ball, W.D.; Marchetti, L.; Hand, A.R. Contributions of intercalated duct cells to the normal parenchyma of submandibular glands of adult rats. Anat. Rec. 2001, 263, 202-214.

76. Man, Y.G.; Ball, W.D.; Culp, D.J.; Hand, A.R.; Moreira, J.E. Persistence of a perinatal cellular phenotype in submandibular glands of adult rat. J. Histochem. Cytochem. 1995, 43, 1203-1215.

77. Aure, M.H.; Konieczny, S.F.; Ovitt, C.E. Salivary gland homeostasis is maintained through acinar cell self-duplication. Dev. Cell 2015, 33, 231-237. 
78. Fujimoto, T.; Yoshimoto, K.; Fujimura, T.; Takeda, M.; Itaya-Hironaka, A.; Takasawa, S. New aspects of mechanism of salivary gland dysfunction in Sjögren's syndrome. In Sjögren's Syndrome; Hernandez, E.M., Ed.; Nova Scientific Publishers, Inc.: New York, NY, USA, 2014; pp. 125-158.

79. Atkinson, J.C.; Grisius, M.; Massey, W. Salivary hypofunction and xerostomia: Diagnosis and treatment. Dent. Clin. North Am. 2005, 49, 309-326.

80. Fox, P.C. Salivary enhancement therapies. Caries Res. 2004, 38, 241-246.

81. Ishiki, Y.; Ohnishi, H.; Muto, Y.; Matsumoto, K.; Nakamura, T. Direct evidence that hepatocyte growth factor is a hepatotrophic factor for liver regeneration and has a potent antihepatitis effect in vivo. Hepatology 1992, 16, 1227-1235.

82. Nakamura, T.; Nishizawa, T.; Hagiya, M.; Seki, T.; Shimonishi, M.; Sugimura, A.; Tashiro, K.; Shimizu, S. Molecular cloning and expression of human hepatocyte growth factor. Nature 1989, 342, 440-443.

83. Nakagawa, K.; Takasawa, S.; Nata, K.; Yamauchi, A.; Itaya-Hironaka, A.; Ota, H.; Yoshimoto, K.; Sakuramoto-Tsuchida, S.; Miyaoka, T.; Takeda, M.; et al. Prevention of Reg I-induced $\beta$-cell apoptosis by IL-6/dexamethasone through activation of $H G F$ gene regulation. Biochim. Biophys. Acta 2013, 1833, 2988-2995.

84. Azuma, M.; Sato, M. Morphogenesis of normal human salivary gland cells in vitro. Histol. Histopathol. 1994, 9, 781-790.

85. Fujimura, T.; Fujimoto, T.; Itaya-Hironaka, A.; Miyaoka, T.; Yoshimoto, K.; Yamauchi, A.; Sakuramoto-Tsuchida, S.; Kondo, S.; Takeda, M.; Tsujinaka, H.; et al. Interleukin-6/STAT pathway is responsible for the induction of gene expression of REG I $\alpha$, a new auto-antigen in Sjögren's syndrome patients, in salivary duct epithelial cells. Biochem. Biophys. Rep. 2015, 2, 69-74.

86. Hoque, A.T.; Liu, X.; Kagami, H.; Swaim, W.D.; Wellner, R.B.; O'Connell, B.C.; Ambudkar, I.S.; Baum, B.J. Construction and function of a recombinant adenovirus encoding a human aquaporin 1-green fluorescent protein fusion product. Cancer Gene Ther. 2000, 7, 476-485.

87. Zheng, C.; Baum, B.J. Including the p53 ELAV-like protein-binding site in vector cassettes enhances transgene expression in rat submandibular gland. Oral Dis. 2012, 18, 477-484.

88. Watanabe, R.; Hanawa, H.; Yoshida, T.; Ito, M.; Isoda, M.; Chang, H.; Toba, K.; Yoshida, K.; Kojima, M.; Otaki, K.; et al. Gene expression profiles of cardiomyocytes in rat autoimmune myocarditis by DNA microarray and increase of regenerating gene family. Transl. Res. 2008, 152, 119-127.

89. Roescher, N.; Tak, P.P.; Illei, G.G. Cytokines in Sjögren's syndrome. Oral Dis. 2009, 15, 519-526.

90. Hulkkonen, J.; Pertovaara, M.; Antonen, J.; Pasternack, A.; Hurme, M. Elevated interleukin-6 plasma levels are regulated by the promoter region polymorphism of the IL6 gene in primary Sjögren's syndrome and correlate with the clinical manifestations of the disease. Rheumatology (Oxford) 2001, 40, 656-661.

91. Szodoray, P.; Alex, P.; Brun, J.G.; Centola, M.; Jonsson, R. Circulating cytokines in primary Sjögren's syndrome determined by a multiplex cytokine array system. Scand. J. Immunol. 2004, 59, 592-599. 
92. Gross, D.J.; Weiss, L.; Reibstein, I.; van den Brand, J.; Okamoto, H.; Clark, A.; Slavin, S. Amelioration of diabetes in nonobese diabetic mice with advanced disease by linomide-induced immunoregulation combined with Reg protein treatment. Endocrinology 1998, 139, 2369-2374.

93. Ghoreschi, K.; Laurence, A.; O’Shea, J.J. Janus kinases in immune cell signaling. Immunol. Rev. 2009, 228, 273-287.

94. Tanaka, Y.; Yamaoka, K. JAK inhibitor tofacitinib for treating rheumatoid arthritis: From basic to clinical. Mod. Rheumatol. 2013, 23, 415-424.

95. van Vollenhoven, R.F.; Fleischmann, R.; Cohen, S.; Lee, E.B.; Garcia Meijide, J.A.; Wagner, S.; Forejtova, S.; Zwillich, S.H.; Grubem, D.; Koncz, T.; et al. ORAL Standard Investigators, Tofacitinib or adalimumab versus placebo in rheumatoid arthritis, N. Engl. J. Med. 2012, 367, 508-519.

96. Fox, P.C. Salivary enhancement therapies. Caries Res. 2004, 38, 241-246.

97. Santavirta, N.; Konttinen, Y.T.; Törnwall, J.; Segerberg, M.; Santavirta, S.; Matucci-Cerinic, M.; Björvell, H. Neuropeptides of the autonomic nervous system in Sjögren's syndrome. Ann. Rheum. Dis. 1997, 56, 737-740.

(C) 2015 by the authors; licensee MDPI, Basel, Switzerland. This article is an open access article distributed under the terms and conditions of the Creative Commons Attribution license (http://creativecommons.org/licenses/by/4.0/). 